\title{
Fetal NGF Augmentation Preserves Excess Trigeminal Ganglion Cells and Interrupts Whisker-related Pattern Formation
}

\author{
Theodore A. Henderson, ${ }^{1}$ Eugene M. Johnson Jr., ${ }^{2}$ Patricia A. Osborne, ${ }^{2}$ and Mark F. Jacquin ${ }^{1}$ \\ 'Department of Anatomy and Neurobiology, St. Louis University School of Medicine, St. Louis, Missouri 63104 and \\ ${ }^{2}$ Department of Molecular Biology and Pharmacology, Washington University School of Medicine, St. Louis, Missouri \\ 63110
}

In the developing nervous system, precisely patterned connections result from mechanisms that remodel initially diffuse connections. For example, ocular dominance column formation depends upon activity-based competitive interactions. In the developing trigeminal (V) somatosensory system, injury to afferent inputs prevents somatotopic pattern formation; however, afferent impulse blockade does not. What establishes central $v$ patterns remains unclear. As a first step in assessing the role of neurotrophins in naturally occurring death of $\mathbf{V}$ ganglion cells and whisker-related pattern formation, the consequences of prenatal NGF injections were evaluated. Fetal rats given NGF on both embryonic day (E) 15 and $E 18$ had $36 \%$ more $V$ ganglion cells than normal and lacked whisker-related patterns in the $V$ brainstem complex at birth and through postnatal day 3 , as determined by cytochrome oxidase histochemistry. Rats injected with NGF on E16 or on E18, or with vehicle had normal ganglion cell numbers and brainstem patterns. Animals injected with antibodies to NGF or an NGF receptor had reduced ganglion cell numbers and normal brainstem patterns. These findings suggest that naturally occurring cell death in the $\mathbf{V}$ ganglion is neurotrophically regulated and that this process impacts upon somatotopic pattern formation in the V brainstem complex.

Results of anterograde tracing experiments in NGF-augmented animals suggest that pattern disruptions are due to an absence of whisker-related patterning in the central projections of $\mathbf{V}$ ganglion cells. Moreover, single primary afferent collaterals labeled by Neurobiotin injections in the $V$ ganglion did not have widespread or unusually complex arbors. Thus, NGF may affect $V$ pattern formation by preserving or inducing projections to brainstem regions that normally come to lack such projections, such as the spaces

\footnotetext{
Received Apr. 26, 1993; revised Nov. 5, 1993; accepted Dec. 16, 1993.

This work was submitted by T.A.H. in partial fulfillment of the requirements for a Ph.D. in Neurobiology at St. Louis University. The technical assistance of Dr. Vernon W. Fischer and Mrs. Nanci Hobart is gratefully acknowledged. Thanks to Drs. T. A. Woolsey, D. S. Zahm, and R. W. Rhoades for helpful discussions during the course of these experiments. This work was supported by NIH Grants DE07734, DE07662, NS17763, and NS24679, and the Parrett Scholarship Foundation.

Correspondence should be addressed to Dr. Mark Jacquin, Department of Anatomy and Neurobiology, St. Louis University School of Medicine, 1402 South Grand Boulevard, St. Louis, MO 63104.

Copyright (C) 1994 Society for Neuroscience $0270-6474 / 94 / 143389-15 \$ 05.00 / 0$
}

normally demarcating neighboring whisker primary afferent projections.

[Key words: barrels, trigeminal, somatotopy, NGF, development, cell death, pattern formation, vibrissae]

A number of unique architectural features develop in the CNS to subserve distinct functional properties. For example, in rodents, the spatial arrangement of the mystacial whiskers is represented in the S1 somatosensory cortex by an orderly patterning of afferent terminals, neuronal somata, and dendritic processes, which appear as an array of patches or "barrels" (Woolsey and Van der Loos, 1970). Analogous whisker-related patterns are found in the trigeminal (V) nuclcus principalis (PrV), the spinal $\mathrm{V}$ subnuclei interpolaris ( $\mathrm{SpVi}$ ) and caudalis $(\mathrm{SpVc})$, and the ventroposteromedial thalamus (Van der Loos, 1976; Woolsey, 1978; Belford and Killackey, 1979a,b; Erzurumlu et al., 1980; Ma and Woolsey, 1984; Bennett-Clarke et al., 1992). In the V brainstem nuclei, patterns are composed of an aggregated array of columns of afferent terminals and postsynaptic neuronal processes running rostrocaudally in the brainstem (Arvidsson, 1982; Ma and Woolsey, 1984; Jacquin et al., 1993, in press) that are responsive predominately to the somatotopically appropriate whisker (Jacquin et al., 1988a; Jacquin, 1989).

Like many other portions of the CNS, central V nuclei receive initially diffuse, though topographic, inputs early in development (Dawson and Killackey, 1985; Erzurumlu and Jhaveri, 1990, 1992). During late prenatal and early postnatal life, central $\mathrm{V}$ axons and cells become parcellated into somatotopic patterns (Rice and Van der Loos, 1977; Jacquin and Rhoades, 1987; Killackey et al., 1990; Rhoades et al., 1990; Schlaggar and O'Leary, 199 la; Senft and Woolsey, 1991; Chiaia et al., 1992a). How these patterns form remains to be elucidated because, to date, the only manipulation known to prevent central $\mathrm{V}$ pattern formation is interruption of the afferent pathway (e.g., Van der Loos and Woolsey, 1973; Killackey and Fleming, 1985; Killackey et al., 1990; Rhoades et al., 1990; Woolsey, 1990). Other experiments have demonstrated that barrels are not an inherent property of somatosensory cortex (Schlaggar and O'I eary, $1991 \mathrm{~b}$ ), but are induced by thalamocortical afferents. The mechanism by which patterning information is transmitted centrally by $\mathrm{V}$ afferents remains unknown.

One potential instructional mechanism, with precedent in the visual system (e.g., Reh and Constantine-Paton, 1985), is activity-dependent competitive interactions. However, the $\mathrm{V}$ systcm may be distinct, because recent studies indicate that neuronal impulse blockade does not prevent the development of 


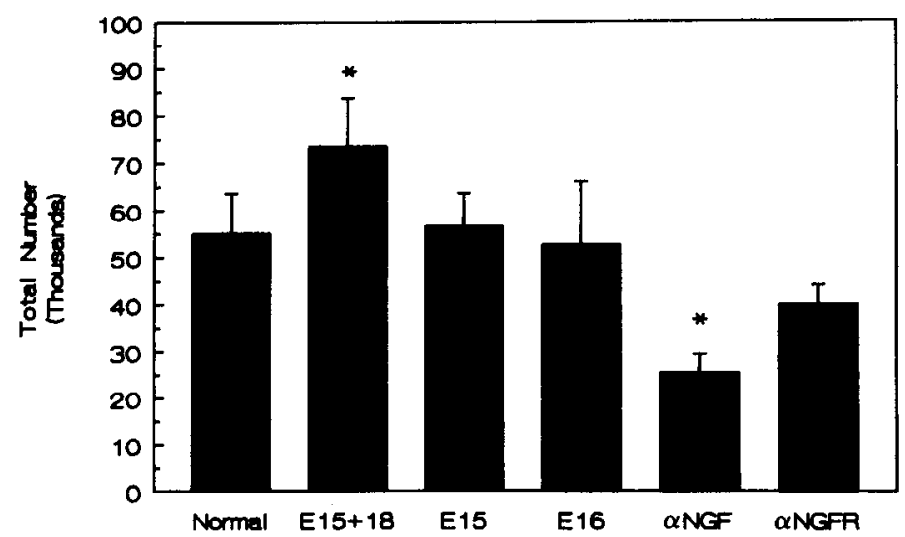

Figure l. Stereological analysis of trigeminal $(V)$ ganglion cell numbers revealed consistent treatment effects. Single injections of NGF at E15 or E 16 had no effect on cell number at birth $(t=0.3, p=0.40 ; t=0.2$, $p=0.43$, respectively). However, newborn animals that received 20 $30 \mu \mathrm{g}$ doses of NGF on E15 and again on E18 had significantly more (36\%) ganglion cells than age-matched normal animals $(t=3.7, p<$ $0.01)$.

somatotopic patterns throughout the V neuraxis (Chiaia et al., 1992b; Henderson et al., 1992b). This perhaps is not surprising in light of evidence that levels of spontaneous and stimulusevoked neuronal activity are extremely low in the $V$ system prior to and during the periods of whisker-related pattern formation (Armstrong-James and Fox, 1987; Chiaia et al., 1993). The lack of a role for impulse activity in the development of somatosensory patterns is in contrast to the developing visual system, in which high levels of patterned spontaneous impulses form the substrate for competitive interactions that lead to patterning of central visual pathways (reviewed in Shatz, 1990).

An alternative patterning mechanism(s) could be related to the known influences of neurotrophins on the devcloping somatosensory system. By way of background, the first $\mathrm{V}$ ganglion cells are born on or around embryonic day (E) 10 in rat (Forbes and Welt, 1981; Rhoades et al., 1991) and E9 in mouse (Davies and Lumsden, 1984). Shortly after their axons contact the epithelium, these cells upregulate expression of receptors for NGF (Davies et al., 1987), the prototypic "neurotrophin," which is a trophic factor for sympathetic, neural crest-derived sensory, and some central, neurons (reviewed in Levi-Montalcini, 1987). During the period of peripheral target innervation (E14-E19), mouse ganglion cells placed in culture are NGF dependent (Davies et al., 1981, 1987). Davies and colleagues have suggested that a cycle of neuron death begins coincident with NGF receptor upregulation, wherein an estimated $50 \%$ of these primary sensory neurons die (Davies and Lumsden, 1984; Davies et al., 1987). Furthermore, high titers of antibodies to NGF during fetal life result in an exacerbation of naturally occurring cell death with the loss of about $80 \%$ of the $\mathrm{V}$ ganglion cells that would normally survive (Sikich et al., 1986). Taken together, these data suggest that NGF, or more specifically a limiting supply of NGF, is important in controlling naturally occurring cell death in the $\mathrm{V}$ ganglion. Whether this process impacts on central $\mathrm{V}$ pattern formation has yet to be determined.

As a first step in assessing the role of neurotrophins in naturally occurring death of $\mathrm{V}$ ganglion cells and whisker-related pattern formation, the consequences of prenatal NGF injections were evaluated.
Portions of this work have been published in abstract form (Henderson et al., 1991, 1992a).

\section{Materials and Methods}

Preparation of nerve growth factor and antisera. The $2.5 \mathrm{~S}$ subunit of NGF, purified from adult male mouse submandibular glands by a modification of the method of Bocchini and Angeletti (1969), was used in all experiments. NGF was assayed by a biological assay utilizing chick dorsal root ganglion explants (Fenton, 1970). Consistent levels of activity were found in all preparations used. Unfractionated goat antimouse 2.5 S NGF serum was tested in the same bioassay and prevented NGF-induced neurite outgrowth at dilutions of at least $1: 10,000$. The mouse monoclonal antibody directed against the low-affinity NGF receptor (192-IgG) was prepared from hybridoma cell lines by methods detailed in Taniuchi and Johnson (1985).

In utero injections and processing of animals. Fetuses from timed pregnant, multiparous, Spraguc-Dawlcy rats (Harlan Spraguc-Dawlcy) were used for all experiments. Methods for their care and use adhered to institutional and federal guidelines. Timed pregnancies were obtained by placing an experienced male with a female for $12 \mathrm{hr}$. Gestation was 21.5-22 d. Pregnant dams were anesthetized with $0.7 \mathrm{ml} / \mathrm{kg}$ of a cocktail of 3 parts each of $100 \mathrm{mg} / \mathrm{ml}$ ketamine and $20 \mathrm{mg} / \mathrm{ml}$ xylazine, and 1 part $10 \mathrm{mg} / \mathrm{ml}$ acepromazine. Sterile technique was used in all procedures. The uterine horns were individually lifted through a midline abdominal incision. Each pup, beginning with the most rostral, was visualized with fiber-optic lights and injected subcutaneously in the middorsal or rump region with $10 \mu$ of solution via a $100 \mu$ l Hamilton syringe and a 30 gauge needle. After the uterine horns were gently replaced, the peritoneum and muscle wall were closed with nonresorbable suture; the skin was closed with suture and Michel clips. Dams undergoing a sccond surgery wcre ancsthetized with the same cocktail and the original incision was carefully reopened.

Neonatal pups were anesthetized and perfused within $4 \mathrm{hr}$ of delivery, or allowed to survive for 1 or $3 \mathrm{~d}$ postnatally (P1, P3). The perfusates were heparinized saline, followed by a lysine/paraformaldehyde fixative composed of $0.066 \mathrm{M}$ lysine $\mathrm{HCl}, 0.033 \mathrm{~m}$ sodium phosphate, and $2.6 \%$ (v/v) paraformaldehyde (McLean and Nakane, 1974).

Tissue processing. Brainstems were frozen sectioned at $60 \mu \mathrm{m}$ in the coronal plane on a sliding microtome and processed for cytochrome oxidase histochemistry. Briefly, sections were rinsed and stored in 0.1 M phosphate buffer ( $\mathrm{pH} 7.4)$. An incubation medium containing 100 mg of diaminobenzidine (Sigma), $44 \mathrm{mg}$ cy tochrome C (type III, Sigma), and $8 \mathrm{gm}$ of sucrose in $180 \mathrm{ml}$ of phosphate buffer was saturated with $5 \% \mathrm{CO}_{2} / 95 \% \mathrm{O}_{2}$ for $10 \mathrm{~min}$ (Wong-Riley, 1979). Free-floating sections were incubated at $37^{\circ} \mathrm{C}$ for $12-24 \mathrm{hr}$ and arrested with three rinses in phosphate buffer when there was clear differentiation of cytochrome oxidase-positive structures (e.g., V motor nucleus, inferior olive, whisker-related patches, if present). Sections were plated onto electrostatic glass slides (Superfrost Plus, Fisher), allowed to air dry, dehydrated in $100 \%$ alcohol, cleared in xylene, and coverslipped with Permount or Cytoseal (Stephens Scientitic).

The left $\mathrm{V}$ ganglion was removed for cell counts. Paraffin-embedded ganglia were serially sectioned in the horizontal plane at $10 \mu \mathrm{m}$ on a sliding microtome. After staining the sections with cresyl violet, the tissue was differentiated with acetic acid $/ 50 \%$ alcohol. Sections were dehydrated, cleared, and coverslipped as above.

Experimental design. Prenatal NGF supplementation was produced by injecting fetuses in utero with $20-30 \mu \mathrm{g}$ of NGF. Animals were given single doses of NGF at one of three time points, on E15 $(N=7)$, E16 $(N=3)$, or $\mathrm{E} 18(N=3)$. Other fetuses received NGF on both E15 and E18 $(N=66)$. All of these animals were killed at the time of natural birth, or at the time of cesarian section on E22 if natural delivery did not occur. Controls were injected with a matching volume of vehicle $(N=27)$. In other cases allowed to survive through P1 $(N=4)$ or P3 $(N=6)$, after having received NGF injections on both $\mathrm{E} 15$ and $\mathrm{E} 18$, $30 \mu \mathrm{g}$ of NGF was also injected on every postnatal day until they were killed. A second series of animals $(N=8)$ were injected with a goat antiserum to mouse 2.5 S NGF (Johnson et al., 1989) on E15 and E18 and perfused at birth to test the effects of prenatal NGF deprivation. A third series of animals $(N=3)$ received prenatal injections of 192-IgG on $E 15$ and $E 18$, and were perfused at birth. All experimental and control animals were weighed prior to death.

Brainstems from all animals were analyzed for the distribution of cytochrome oxidase reaction product, a marker of postsynaptic ele- 

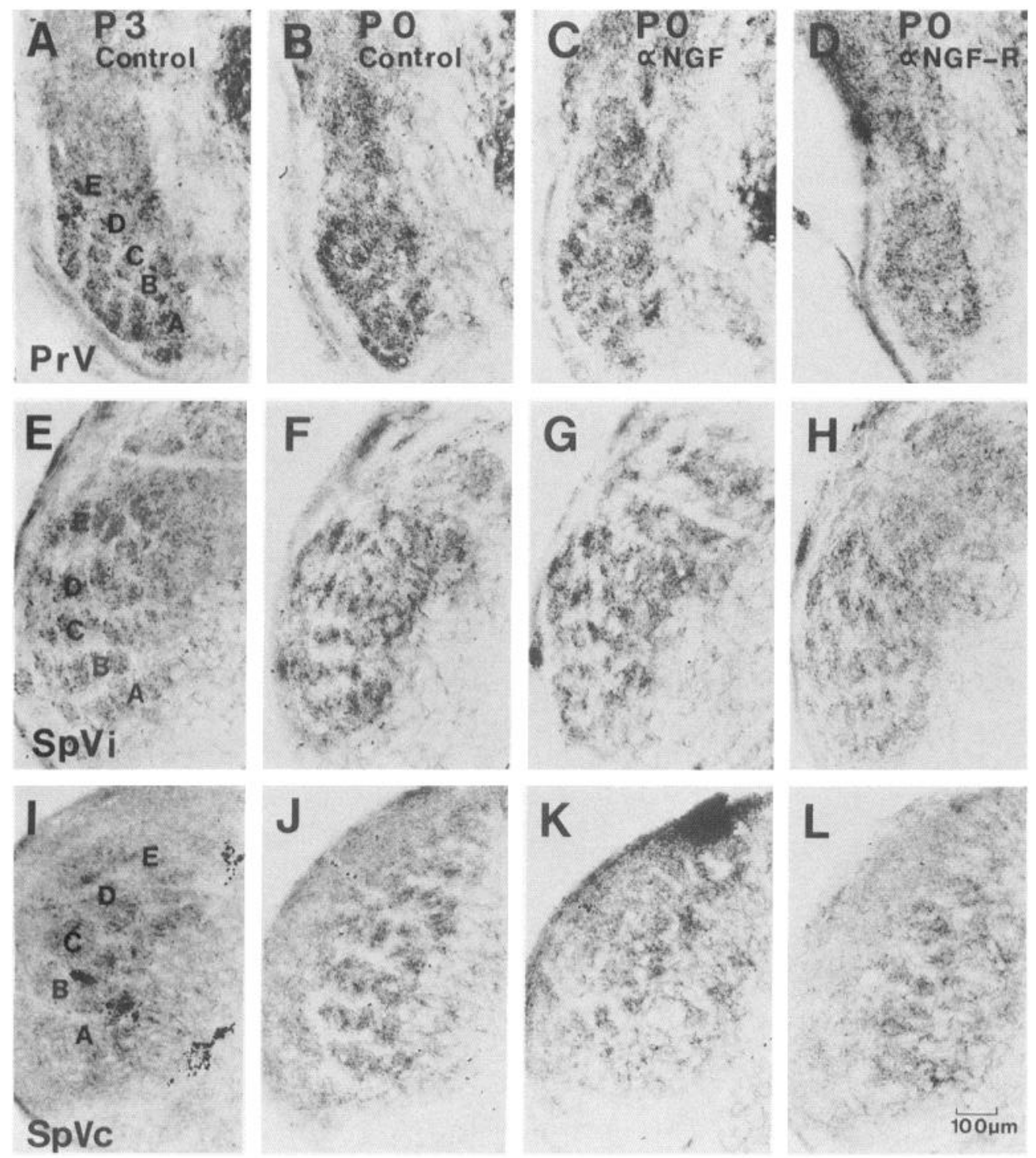

Figure 2. Cytochrome oxidase staining patterns in the $\mathrm{V}$ brainstem complex from vehicle control and NGF antibody cases. Whisker-related patterns are distinct by $\mathrm{P} 3$ in $\operatorname{PrV}(A), \mathrm{SpVi}(E)$, and $\mathrm{SpVc}(I)$. Although less pronounced than at P3, whisker-related patterns are present at birth $(\mathrm{P} 0)$ in vehicle controls $(B, F, J)$. Similar patterns can be seen on $\mathrm{P} 0$ in rats treated on E15 and E18 with antibodies against NGF $(\alpha N G F ; C, G, K)$, or with antibodies against the NGF low-affinity receptor $(\alpha N G F-R ; D, H, L)$. The A-E whisker row representations are lettered in $A, E$, and $I$. ments, which is first patterned in a "barrel-like" manner on E20 (Chiaia et al., 1992a). Numbers of $\mathrm{V}$ ganglion cells were determined in two to seven animals from the E15 and E16 NGF (single injection), NGF antibody, and control groups, and in 10 animals from the E15 and E18 NGF (double injection) group using a modification of previously described stereological methods (Coggeshall et al., 1984, 1990; Gundersen et al., 1988). Briefly, all cell profiles in every fifth section were counted and a correction factor was determined by comparing several pairs of adjacent sections. The empirically derived factor was the ratio of cells appearing in only one section (tops; e.g., Coggeshall, 1992) to the total number of cells identified.

Anterograde tracing experiments. The results of these experiments and the finding (Chiaia et al., 1991) that cytochrome oxidase staining is not a foolproof marker of afferent input patterns necessitated additional study of the anatomical organization of the brainstem in NGFaugmented animals. Identical methods to those described above were used to inject NGF into 35 fetuses on E15;33 of these received a second NGF injection on E18. On E22, pups were taken by cesarian section and, under hypothermic anesthesia, the left $\mathrm{V}$ ganglion was exposed by aspirating the overlying forebrain. Varying quantities of a tracer cocktail consisting of $2 \%$ Neurobiotin (Vector) and 5\% WGA-HRP (Sigma) in Tris-buffered $\mathrm{KCl}$ were injected by pressure into the $\mathrm{V}$ ganglion through a glass micropipette. Wounds were closed and the pups were placed on a heating pad. Nineteen cases survived for $4-19 \mathrm{hr}$, at which point they were given a barbiturate overdose and perfused intracardially with buffered saline followed by buffered $4 \%$ paraformaldehyde and $0.1 \%$ glu- taraldehyde followed by buffered $10 \%$ sucrose. Brainstems were removed and stored in buffered sucrose overnight, and transverse $100 \mu \mathrm{m}$ frozen sections were taken. One series of alternate sections was processed for Neurobiotin and HRP reaction products using avidin-biotin and nickel-intensified diaminobenzidine histochemistry (Jacquin et al., 1992); the other series was reacted for cytochrome oxidase, as described above (Wong-Riley, 1979). Both series were inspected for potential patterning of reaction products in the $\mathrm{V}$ brainstem complex, as well as labeled axon collaterals that might be sufficiently well isolated to gain some impressions of their general morphologies. Labeling patterns were compared to the same obtained from a group of 10 normal newborns that were processed histochemically in a manner matching that of the NGFtreated cases.

\section{Results}

\section{Ganglion cell numbers}

Analysis of the total number of neurons in the $\mathrm{V}$ ganglion revealed significant treatment effects (Fig. 1). Injection of antibodies to NGF on both E15 and E18 resulted in a 53\% decrease in cell number at birth, relative to controls (one-tailed Student $t$ test; $T=7.418 ; p<0.0001 ; \mathrm{df}=10$ ). In contrast, antibodies to the low-affinity NGF receptor $192-\mathrm{IgG}$ did not markedly reduce $\mathrm{V}$ ganglion cell number when administered at the same 
Figure 3. Animals receiving injections of $20-30 \mu \mathrm{g}$ of NGF on E15 and again on E1 8 failed to develop whiskerrelated cytochrome oxidase staining patterns in the $\mathrm{V}$ brainstem complex by birth (two cases). As compared to agematched vehicle controls $(A)$, staining in $\mathrm{SpVi}$ was of varying intensity and patchiness, ranging from haphazard patches unrelated to peripheral structures $(B$ and $F)$ to a homogeneous light reaction product $(C$; note that unstained axon bundles occur normally) to a homogeneous dark reaction product $(D)$. Staining in PrV also lacked indications of somatotopic patchiness.
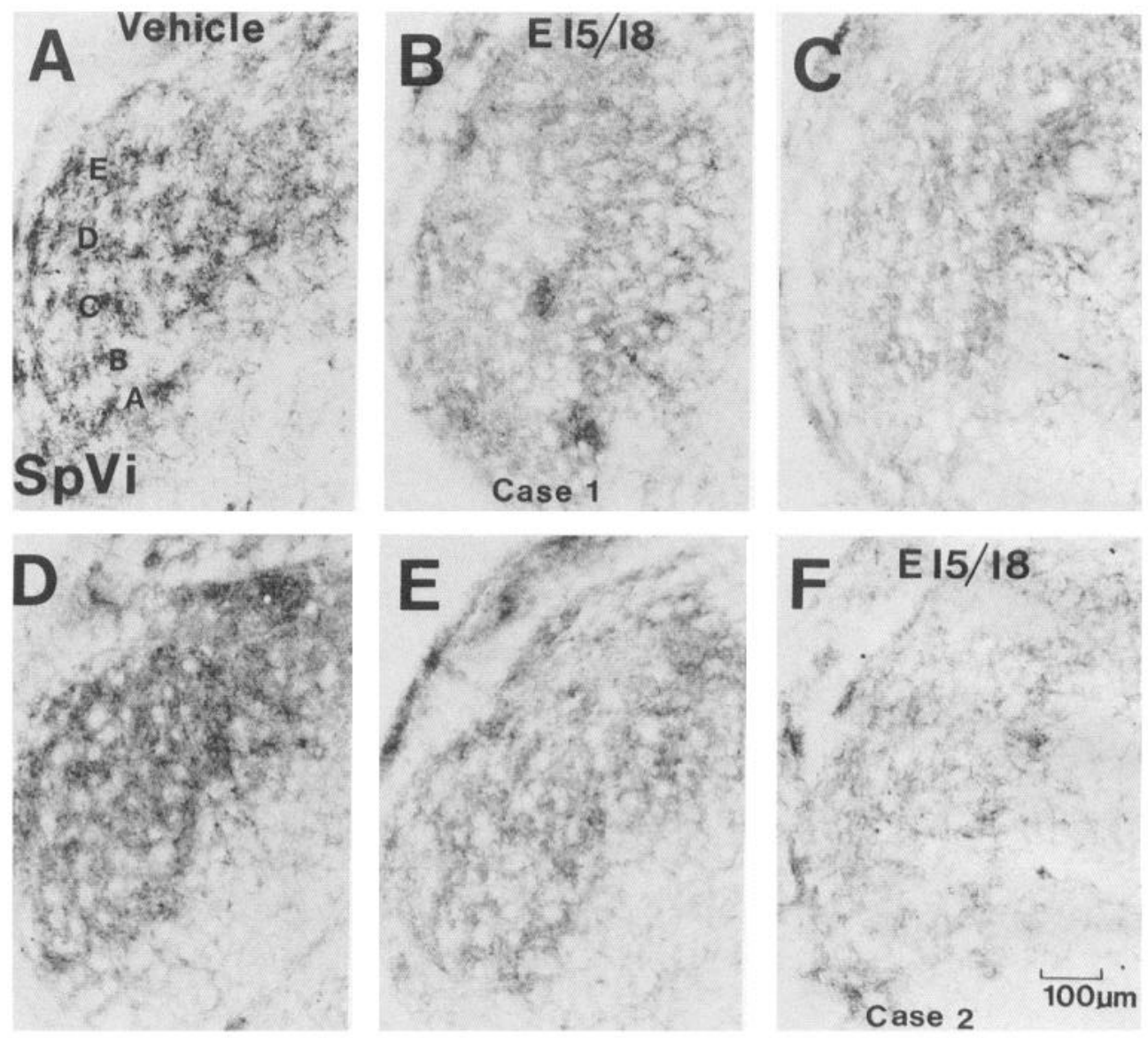

time points during gestation. Mean cell number was reduced by $26 \%$, but this difference from controls fell short of statistical significance $(T=2.01 ; p=0.0506 ; \mathrm{df}=5)$. Single doses of NGF at E15 had no significant effect $(T=0.341 ; p=0.397 ; \mathrm{df}=6)$. Similarly, single doses of NGF on E16 had no significant effect $(T=-0.228 ; p=0.431 ; \mathrm{df}=6)$. Animals receiving NGF on both E15 and E18 had significantly more (36\%) ganglion cells than age-matched controls $(T=-3.748 ; p<0.0009 ; \mathrm{df}=16)$.

\section{Whisker-related patterns in the brainstem}

Cytochrome oxidase staining in control animals revealed whisker-related patterns on the day of birth ( $\mathrm{P} 0)$ that became progressively more distinct during the first few postnatal days (Fig. 2). Rows of cytochrome-dense patches are separated and divided by cytochrome-pale regions, referred to as septa. In $\mathrm{SpVi}$, the representation is most distinct, due to the greater width of the septa compared to other portions of the $\mathrm{V}$ brainstem complex (Fig. 2E). The whisker representation at a given level of SpVc is incomplete, due to the three-dimensional somatotopy of this subnucleus. Individual whiskers are represented by large patches in the magnocellular lamina (Fig. 2I). The superficial laminae are devoid of segmented staining.

In animals injected with antibodies to NGF on E15 and again on E18, whisker-related patterns can be clearly recognized (Fig. $2 C, G, K)$. The cytochrome staining patterns were not distinct from the range of staining seen in normal neonates. While individual patches could not be reliably distinguished in PrV, rows were as distinct as those found in PrV of normal animals; how- ever, distinctive patches could be found in $\mathrm{SpVi}$. These data are consistent with earlier reports of $\mathrm{V}$ pattern formation in rodents deprived of NGF by transplacental transfer of maternal antibodies (Sikich et al., 1986).

In animals injected with 192-IgG, whisker-related patterns were also observed in the brainstem (Fig. $2 D, H, L$ ). The whiskerrelated patterns in these cases were as distinct as those observed in normal neonates with the possible exception of patterns in PrV. In some cases (as illustrated in Fig. 2D), PrV patterns were not well developed at birth.

In animals receiving NGF on both E15 and E18 (E15/E18), there was no evidence of somatotopic staining patterns in the brainstem. Figures 3 and 4 show sections from two cases killed at birth to illustrate the range of patterning and staining intensity in $\mathrm{SpVi}$ and $\mathrm{SpVc}$, respectively. As compared to age-matched controls, cytochrome staining in $\mathrm{SpVi}$ was of varying intensity and patchiness, ranging from haphazard patches (Fig. $3 B, F$ ) to a homogeneous light reaction product (Fig. $3 C$; note that unstained axon bundles occur normally) to a homogeneous dark reaction product (Fig. $3 D$ ). Staining in $\mathrm{SpVc}$ led to a similar impression, with no indications of somatotopic patchiness. Reaction product was diffuse, save for a greater than normal number of unstained axon bundles in superficial laminae.

By contrast, in animals given single doses of NGF on E16 (Fig. $5 A, D, G$ ) or on E18 (not illustrated), whisker-related patterns at birth were indistinguishable from controls. The only instance of an intermediate effect was observed after treating animals with a single dose of NGF on E15. While whisker- 

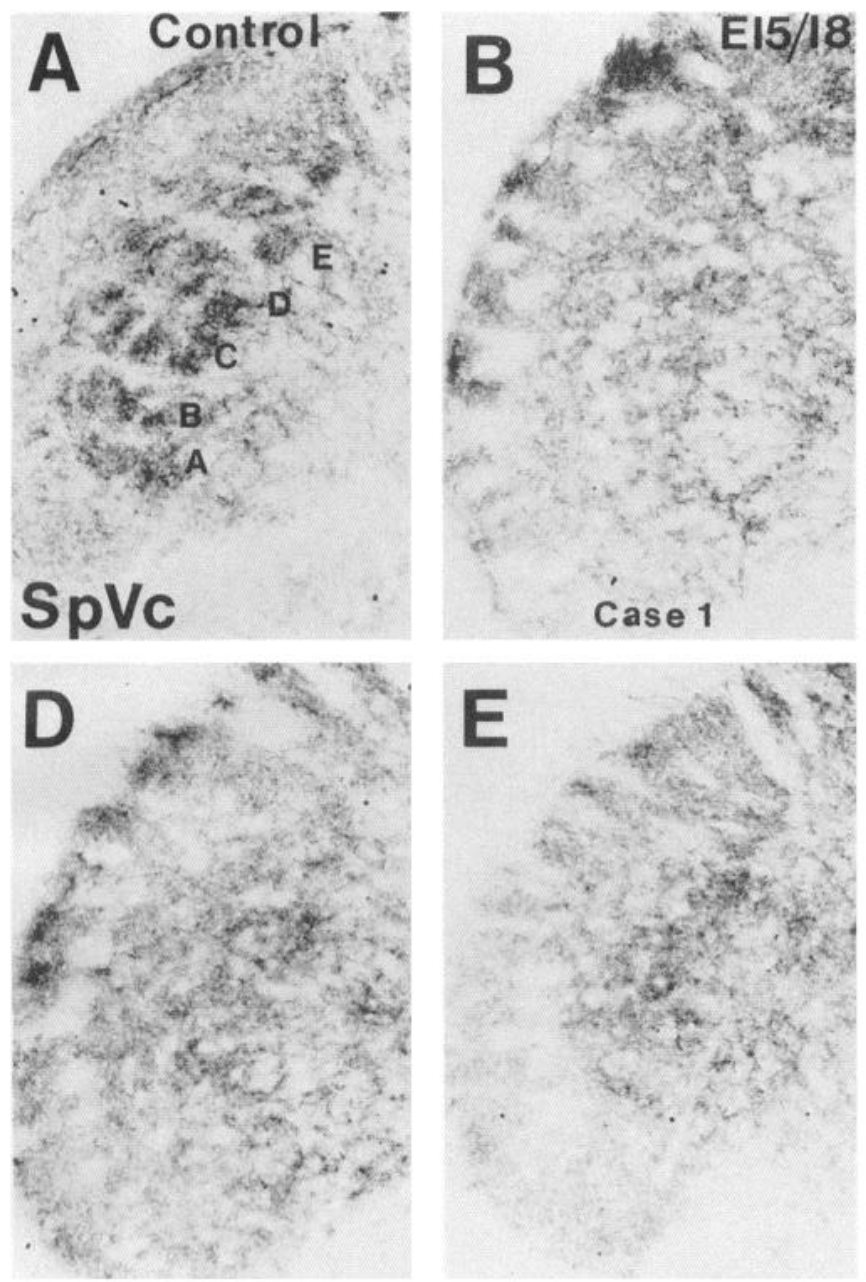

related patterns could still be detected, the clarity of whiskerrelated patterns ranged considerably and was distinct from that seen among control neonates. Two cases bracketing the variability in staining intensity and clarity are provided in Figure $5, B, E$, and $H$ and $C, F$, and $I$, respectively. In some cases, a portion of the pattern was distinct (e.g., Fig. $5 E$ ), while in other cases only row-related staining could be discerned (e.g., Fig. $5 C$ ).

Insofar as malnutrition is known to retard the development of cortical barrels (Vongdokmai, 1980), birthweight is an important variable. All animals undergoing surgical manipulation had reduced bodyweight at birth, including those receiving vehicle only. Birthweight was reduced to a mean of $4.26 \mathrm{gm}$, compared to a mean of $5.5 \mathrm{gm}$ in normal newborns $(p<0.0001)$; however, NGF-treated cases did not differ from vehicle controls or animals treated with anti-NGF or 192-IgG (ANOVA, $F=$ $2.1 ; p=0.13$ ).

Animals that had received injections of NGF on E15 and E18, and were maintained postnatally with supplemental doses of NGF also failed to develop whisker-related patterns. The latter could be prevented for at least $3 \mathrm{~d}$ postnatally, which is as far as these experiments were run. Lesser postnatal doses were not effective in preventing the emergence of somatotopic patterns (not illustrated). Figure 6 illustrates the results from a representative case killed on P1. Note the absence of whiskerrelated staining in all three $\mathrm{V}$ subnuclei. Similarly, a represen-
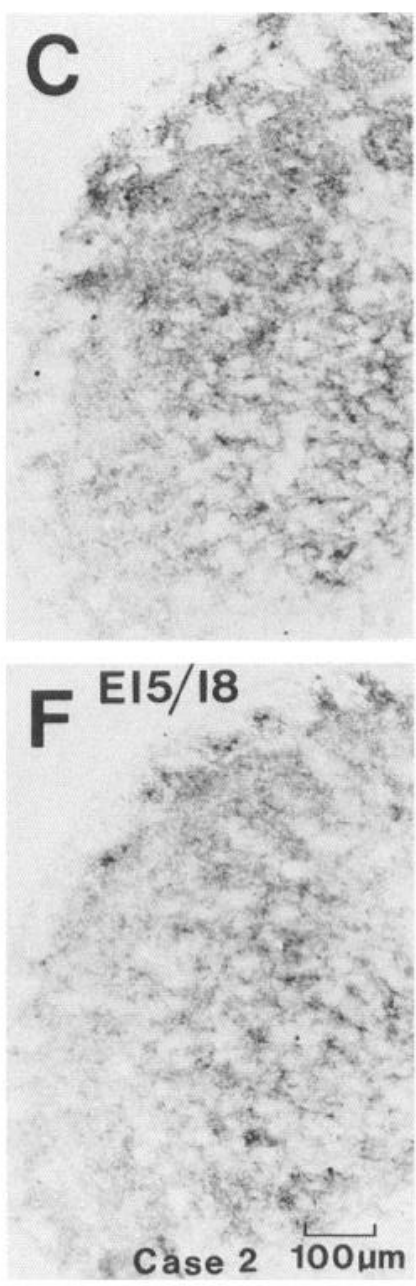

Figure 4. NGF administration on both E15 and E18 also led to the failure of pattern formation in $\mathrm{SpVc}$ by birth. A control section $(A)$ shows whisker-related patterns in the magnocellular portion of SpVc. Two experimental cases $(B-E$ and $F)$ illustrate the range of staining observed. tative animal receiving the same treatment for the first 3 postnatal $\mathrm{d}$ failed to display whisker-related segmentation in the $\mathrm{V}$ brainstem complex (Fig. 6).

\section{Anterogradely labeled primary afferents}

Anterograde labeling of $\mathrm{V}$ primary afferent projections on the day of birth following fetal NGF augmentation permitted analysis of primary afferent termination patterns and general features of single collateral arborizations. Neurobiotin/HRP injections into the $\mathrm{V}$ ganglion of newborn rats that had received NGF injections on E15 and E18 robustly labeled primary afferent endings in the $\mathrm{V}$ brainstem complex. In no case were labeled elements patterned in any discernable somatotopic fashion. In those cases displaying the most extensive transport and effective labeling of terminals in all parts of the $\mathrm{V}$ brainstem complex (Fig. 7A), staining was diffuse and continuous, like the staining obtained in adjacent sections reacted for cytochrome oxidase activity (Fig. $7 B$ ). Inspection of the anterograde labeling at higher magnifications (Fig. $7 C, D$ ) led to the same impression of an absence of patterning and further indicated that the darkest reaction product was confined to axon branches and terminals; lighter reaction product appeared confined to terminals only. Transsynaptic cellular labeling was never observed in the $\mathrm{V}$ brainstem complex.

In the remaining cases where anterogradely labeled fibers and terminals occurred in only a portion of the $\mathrm{V}$ brainstem com- 

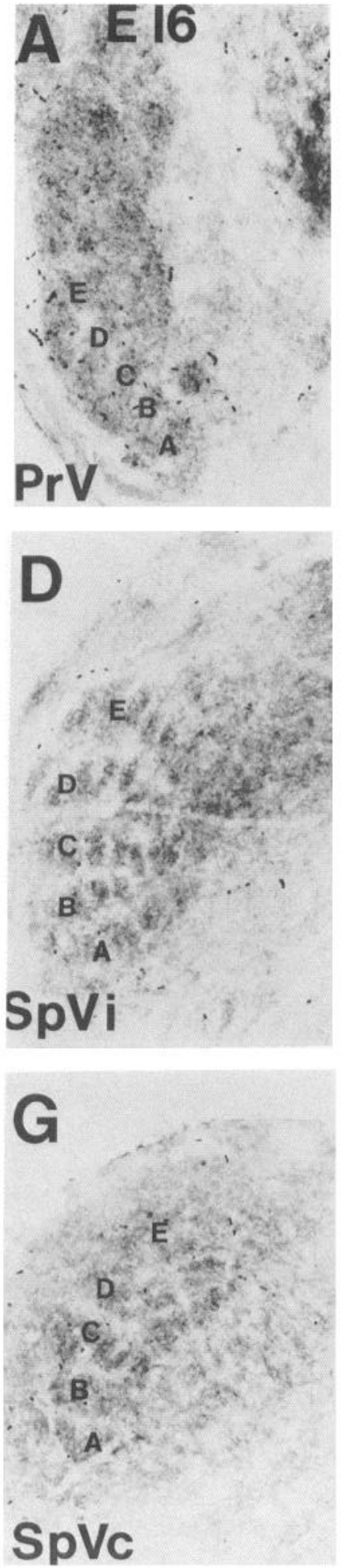
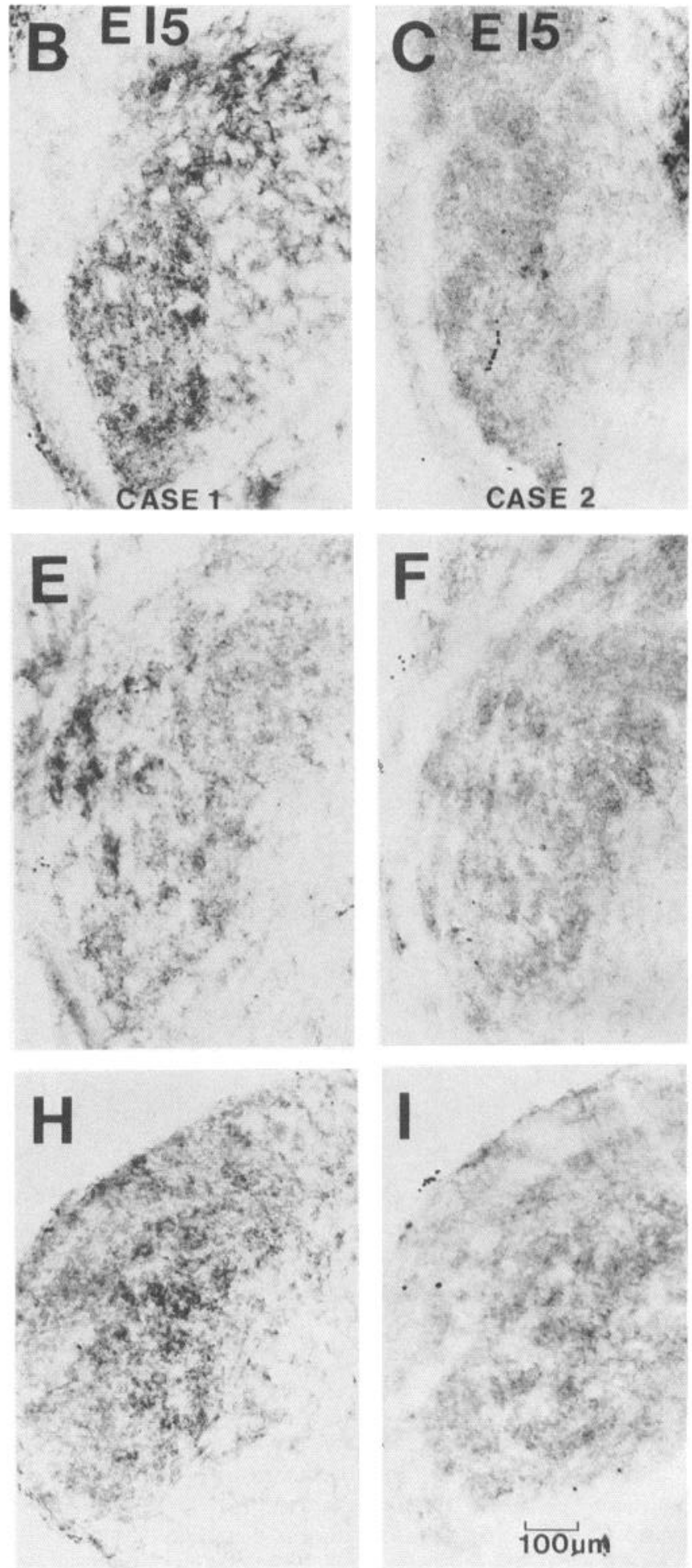

Figure 5. Whisker-related patterns are less distinct on P0 than in vehicle controls following single doses of NGF during early fetal life. Single injections of $30 \mu \mathrm{g}$ of NGF at E16 did not alter V somatotopic patterns present at birth $(A, D, G)$; however, neonatal patterns were less pronounced in animals injected with $30 \mu \mathrm{g}$ of NGF on E15. In some cases, row-related staining was evident (case $1: B, E, H$ ), while in others only faint condensations were detectable (case 2: $C, F, I$ ). plex, single collaterals and their terminal arbors could be viewed. As shown in Figures 8 and 9, from an E15/E18 NGF case where cytochrome oxidase failed to reveal whisker-related segmentation (Figs. $8 A, B ; 9 A, B$ ), single collaterals were heavily labeled in their terminal branches and bouton-like swellings were prominent. Collateral arbors tended to have simple morphologies with "circumscribed" or "stringy" shapes that were certainly smaller and less complex than those previously described from normal adults (Jacquin et al., 1986, 1988, 1993).

\section{Discussion}

Our findings can be summarized as follows. Rats treated systemically with NGF on E15 and again on E18 have more V ganglion cells than normal and fail to develop whisker-related, 

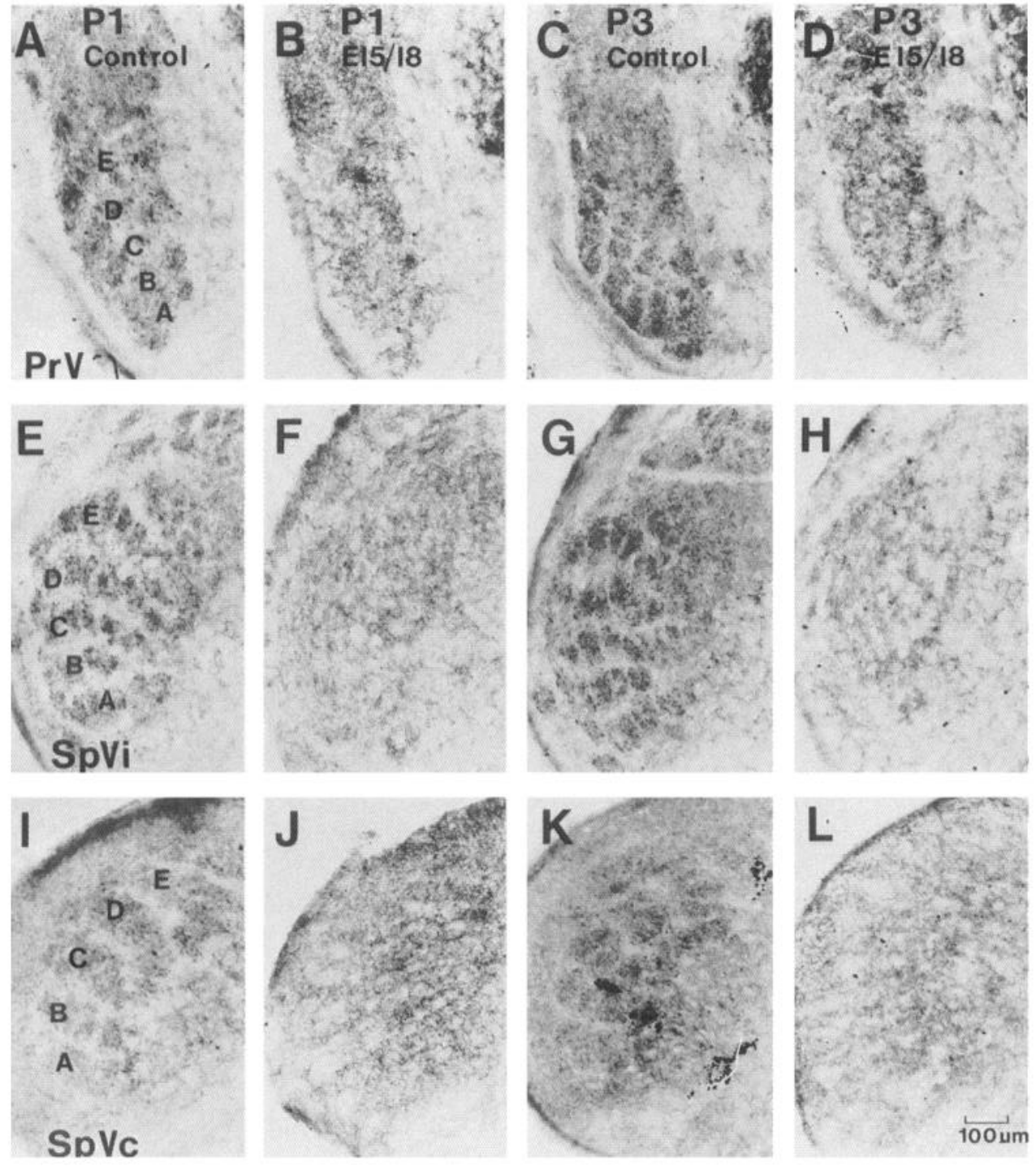

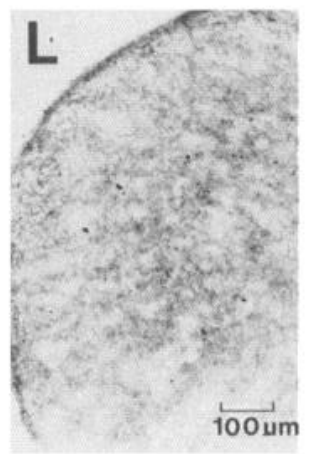

Figure 6. Animals injected with NGF on both E15 and E18, and on each of the first 1-3 postnatal $d$, also lacked whisker-related cytochrome patterns in each of the three $\mathrm{V}$ brainstem subnuclei on $\mathrm{P} 1(B, F, J)$ and $\mathrm{P} 3(D, H, L)$, relative to vehicle controls on $\mathrm{P} 1(A, E, I)$ and $\mathrm{P} 3(C, G, K)$. cytochrome oxidase staining patterns in the $\mathrm{V}$ brainstem complex by the time of birth. Whisker-related patterning is also not evident in the central projections of $\mathrm{V}$ ganglion cells and their collaterals do not have widespread or unusually complex arbors. Whisker-related patterning is also not present in the brainstem $3 \mathrm{~d}$ after birth if NGF augmentation is continued postnatally. Animals receiving a single dose of NGF on E15 have abnormal whisker-related patterns at birth. Those treated with NGF later in gestation or with vehicle demonstrate normal, whisker-related staining patterns. While treatment with antibodies to NGF or NGF receptors reduces $\mathrm{V}$ ganglion cell numbers, central $\mathrm{V}$ pattern formation is not interrupted.

In conjunction with the prior findings of Sikich et al. (1986) in guinea pig, these data suggest that (1) pattern formation proceeds normally after uniform prenatal "underloading" of V primary afferent inputs; (2) whisker-related patterns form normally under conditions of NGF deprivation; (3) pattern formation is not interrupted by nonspecific interactions with antisera; (4) prenatal NGF augmentation rescues many $\mathrm{V}$ ganglion cells from naturally occurring death; (5) prenatal NGF augmentation interrupts whisker-related pattern formation; and (6) these effects are not due to surgical trauma, reduced body weight, reduced metabolic activity in the brainstem, or a nonspecific effect of altering the trophic environment through which central $\mathrm{V}$ axons normally elaborate somatotopic patterns.

While these experiments demonstrate a robust effect of NGF on central $\mathrm{V}$ pattern formation that cannot be attributed to a number of possible confounding variables, caution is warranted in interpreting this finding for three reasons. First, our exclusive study of the $\mathrm{V}$ brainstem complex leaves open the possibility that the NGF effects described here are not reflected in thalamic and cortical pattern alterations. We view this possibility as unlikely given all indications that higher-order $\mathrm{V}$ patterns develop centripetally and sequentially, and that pattern formation in the thalamus and cortex is contingent upon patterns being present in the brainstem (e.g., Killackey and Fleming, 1985; Killackey et al., 1990; Rhoades et al., 1990; Woolsey, 1990). Second, at present we have only limited information on the peripheral projections of V ganglion cells after NGF augmentation. Should exogenous NGF, via its known tropic actions, induce ganglion cells to innervate more than one whisker, or a whisker and adjacent skin, then one need only posit that failed pattern formation reflects an altered peripheral projection pattern. Although preliminary analyses of the infraorbital nerve and its 

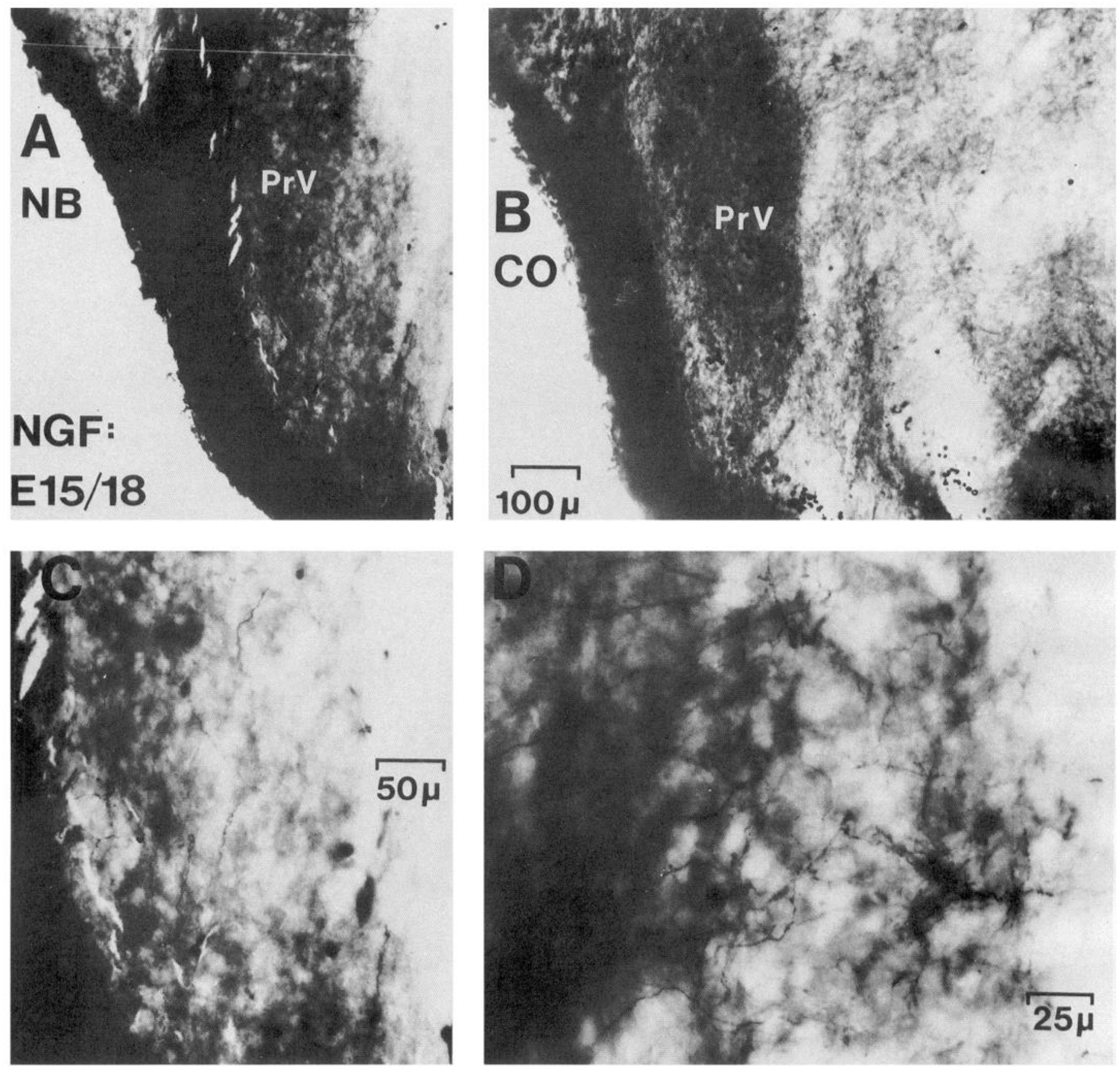

Figure 7. When NGF is given on E15 and again on E18, and a large bolus of Neurobiotin $(N B)$ and WGA-HRP is injected into the left V ganglion at birth, resultant terminal labeling in the left $\operatorname{PrV}$ is not patterned in any obvious way $(A ; 100 \mu \mathrm{m}$ transverse section, ABC-diaminobenzidine reaction, $8 \mathrm{hr}$ transport interval). Cytochrome oxidase $(C O)$ staining in adjacent sections through PrV is not patterned as well $(B)$. Successively higher-magnification, bright-field views of the Neurobiotin labeling shown in $A(C$ and $D)$ also fail to reveal somatotopic patterning, yet axons are well labeled. The scale bar in $B$ also applies to $A$.

peripheral trajectories (Henderson et al., 1992b) suggest that such abnormalities did not occur in the experimental cases presented here, these possibilities should be systematically evaluated. The present description of "simple" collateral arbors in the brainstem following NGF augmentation is also consistent with there being limited, if any, neurotropically induced interwhisker branching of single axons in the periphery. Third, although NGF delivered systemically is not known to cross the

Figure 8. In other newborns treated on E15 and E18 with NGF, Neurobiotin $(N B)$ injections in the left V ganglion heavily labeled the central projections of only a subset of $\mathrm{V}$ primary afferents. Left and right panels are four pairs of corresponding low- and high-magnification views of transverse sections through the rostral V brainstem complex; arrows are placed at identical points in each pair for orientation. An absence of patterned cytochrome oxidase staining is shown in $A$ and $B$. Fortuitously isolated single axon collaterals in $\operatorname{PrV}$ are shown in $C-F$, and in subnucleus oralis in $G$ and $H$. Note the absence of complex arborizations. The scale bar in $C$ also applies to $E$ and $G$; the scale bar in $D$ also applies to $F$ and $H$. 

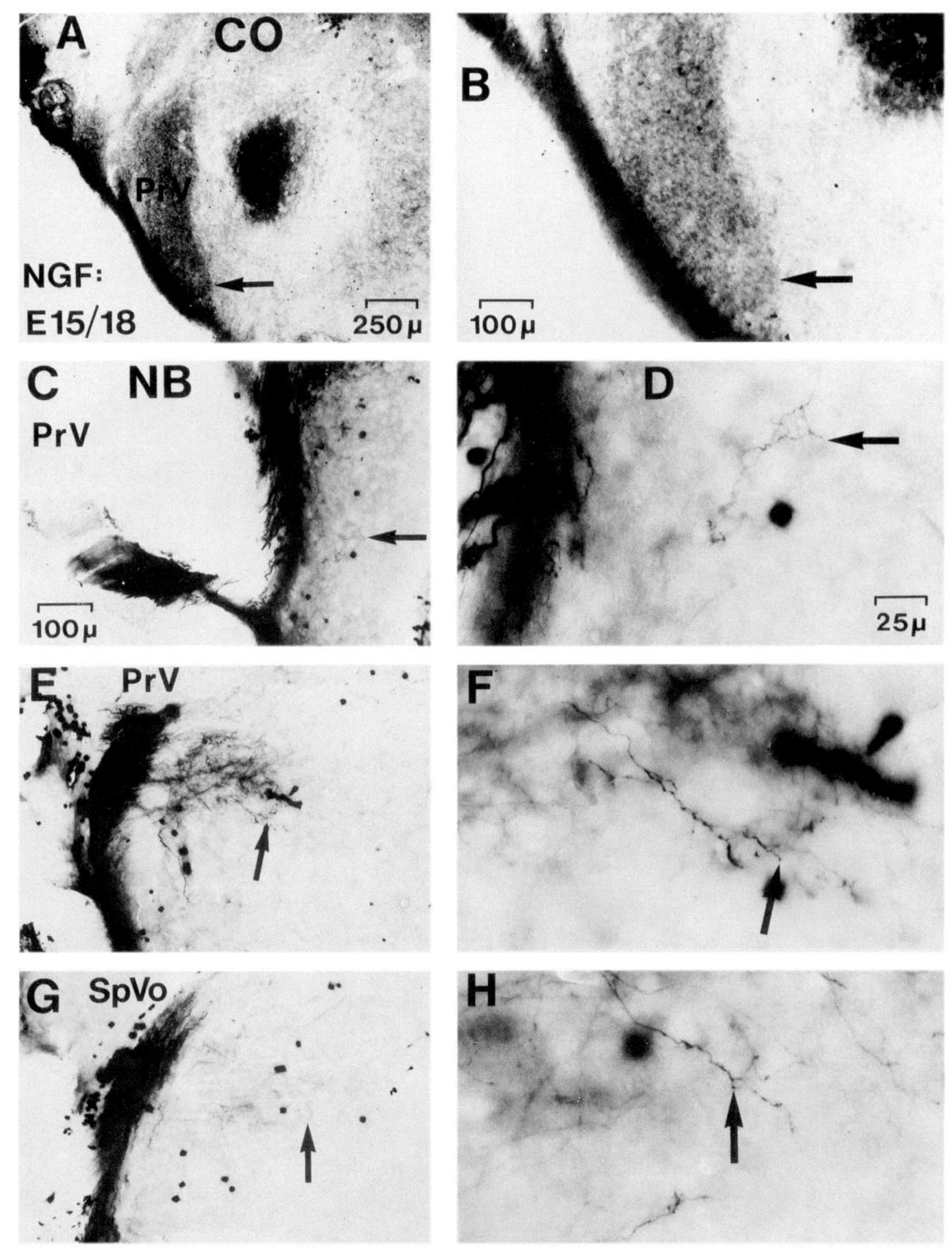

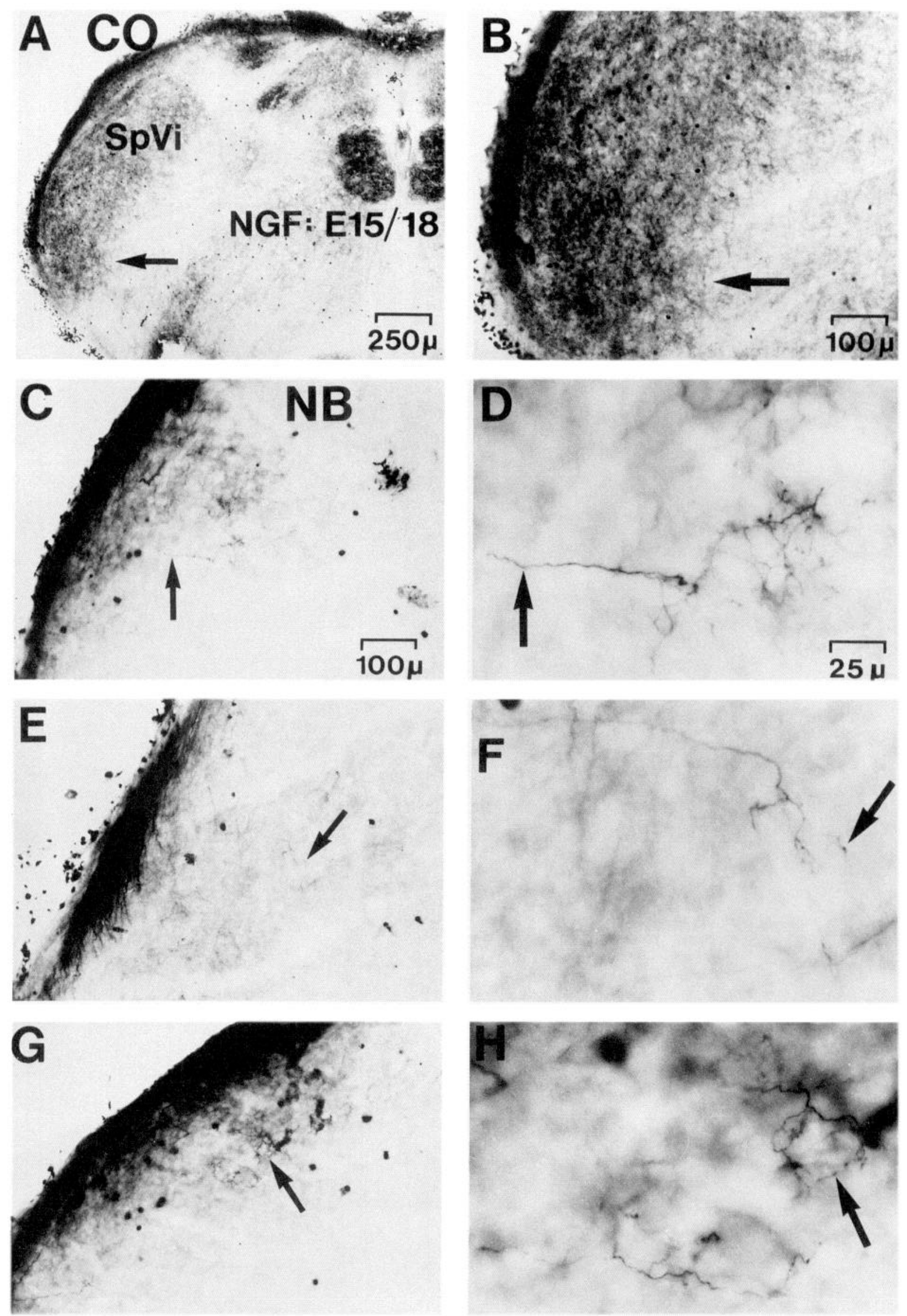
blood-brain barrier (Yip and Johnson, 1984), this possibility was not examined and might be a confounding variable.

\section{Possible mechanisms underlying NGF-induced ganglion cell rescue}

The influence of NGF on naturally occurring cell death in dorsal root ganglia has been well documented. Fetal NGF deprivation by transplacental transfer of maternal antibodies (Gorin and Johnson, 1979; Johnson et al., 1980) results in a roughly 80$85 \%$ reduction in dorsal root ganglion cell number. Surviving cells tended to be larger, suggesting that larger neurons are NGF independent or undergo NGF dependency at earlier developmental time points. Naturally occurring cell death is also exacerbated following fetal exposure to an antibody against the low-affinity NGF receptor (192-IgG) that has been shown to bind noncompetitively to the low-affinity NGF receptor (Chandler et al., 1984) and possibly to the hypothesized subclass of high-affinity NGF receptors formed from the low-affinity receptor and a secondary protein (e.g., Hempstead et al., 1991). Single injections of 192 -IgG on E16 led to a $50 \%$ loss of dorsal root ganglion cells (Johnson et al., 1989). These findings, as well as those presented here, implicate a critical role for NGF during the period of naturally occurring cell death in sensory ganglion cells.

However, it is likely that NGF is not the sole trophic factor influencing sensory neuron survival. Hamburger et al. (1981) have shown that supplemental NGF does not rescue all dorsal root ganglion cells from naturally occurring cell death. While one population was completely rescued by exogenous NGF, a second lost roughly $40 \%$ of the cells that would normally die. Although the authors attributed this to a dosage effect, it may reflect differing trophic requirements. For instance, it is known that brain-derived trophic factor (BDNF) and neurotrophin-3 (NT3) promote neurite outgrowth from some neural crest-derived and placode-derived ganglion cells (Barde et al., 1982; Hohn et al., 1990; Maisonpierre et al., 1990; Hallböök et al., 1991). Carroll et al. (1992) have shown that spinal ganglion cells that survive NGF deprivation selectively express $t r k$-B or $t r k$ $C$, the putative receptors for BDNF and NT-3, respectively (Klein et al., 1991; Lamballe et al., 1991; Soppet et al., 1991; Squinto et al., 1991).

In the $\mathrm{V}$ ganglion, selective $\mathrm{V}$ ganglion cell death would appear to be regulated by a heterogeneous distribution of specific types and amounts of neurotrophic factors in the periphery and the selective expression of different neurotrophic receptors on $\mathrm{V}$ ganglion cells. Two NGF surface receptors have been identified on $\mathrm{V}$ ganglion cells, the low-affinity receptor (dissociation constant, $K_{d}, 10^{-9} \mathrm{M}$ ), corresponding to a $75-80 \mathrm{kDa}$ glycoprotein (Hosang and Shooter, 1985), which is widely distributed (DiStefano and Johnson, 1988; Heuer et al., 1990; Bothwell, 1991), and the trk receptor. Most, if not all, V ganglion neurons express $t r k$ receptor mRNA (Martin-Zanca et al., 1990; Ernfors et al., 1992; Schecterson and Bothwell, 1992). Other members of the trk gene family have also been found in subpopulations of V ganglion cells (Carri et al., 1992; Ernfors et al., 1992), suggesting that other neurotrophins may influence the survival of these cells. As yet, however, the neurotrophin receptor phenotype(s) of those $\mathrm{V}$ ganglion cells that innervate whiskers has not been characterized.

The spatiotemporal patterns of neurotrophin expression in the $\mathrm{V}$ system suggest a role for multiple factors in the orderly regulation of ganglion cell survival. NGF, BDNF, and NT-3 are expressed differentially in the mouse whisker pad. NGF is localized predominately in the epithelial mesenchyme, appearing initially on E11 (mRNA at E10.5) and peaking at E14.5 (Davies et al., 1987; Schecterson and Bothwell, 1992). BDNF is localized to the dermal mesenchyme and its expression is high at E11.5 (Schecterson and Bothwell, 1992), coincident with the ingrowth of $\mathrm{V}$ axons. BDNF message also was found in $\mathrm{V}$ ganglion somata, suggesting an autocrine function (Schecterson and Bothwell, 1992). NT-3 mRNA is also found in dermal mesenchyme, concentrated around the whisker follicles (Ernfors et al., 1992; Schecterson and Bothwell, 1992). Its expression follows a time course similar to that of NGF. Analysis of the peripheral projections of ganglion cells with differing trk phenotypes will be an important next step in assessing why it is that one ganglion cell dies and another does not.

\section{Possible mechanisms underlying NGF-induced pattern alterations}

Regressive processes, such as cell death, process elimination, and dendritic pruning, are known to shape the development of connections in a number of systems (e.g., Innocenti, 1981; Reh and Constantine-Paton, 1983; Greenough and Chang, 1988). To take but one example, O'Leary et al. (1986) demonstrated that those retinal ganglion cells projecting to inappropriate portions of the superior colliculus are eliminated during a phase of naturally occurring cell death (see also Catsicas et al., 1987). In a similar manner, naturally occurring cell death in the $\mathrm{V}$ ganglion may be an integral part of the patterning of connections leading to whisker-related pattern formation. In support of this argument, it is likely that such patterns do not emerge in the brainstem until a major portion of the naturally occurring cell death is complete in the $\mathrm{V}$ ganglion (Davies and Lumsden, 1984; Chiaia et al., 1992b). Moreover, in light of NGF's known effects on axon outgrowth patterns (Levi-Montalcini, 1987) and the demonstrated importance of NGF for $\mathrm{V}$ ganglion cell survival during early development, our finding that NGF augmentation impacts on the emergence of somatotopic patterns further suggests the existence of a previously unrecognized mechanism subserving the development of somatotopic patterns in the central $\mathrm{V}$ neuraxis. We find that serial administration of NGF on E15 and E18, and postnatally prevents the development of whisker-related cytochrome patterns in the brainstem through at least postnatal day 3 , at least 5 d later than when they normally appear in development (Chiaia et al., 1992b). Patterns in animals receiving single injections varied depending on the age at administration.

The actual mechanism subserving NGF augmentation effects on the developing $\mathrm{V}$ brainstem complex is unknown, but should be amenable to experimentation. The following merit followup study. First, as noted above, NGF might induce unusual

\section{$\leftarrow$}

Figure 9. In the same fetal NGF-supplemented case as illustrated in Figure 8, well stained and fortuitously isolated single primary afferent collaterals are visible in transverse sections through the SpVi on the day of birth. At least three separate collaterals are shown at two different magnifications in $C-H$. Here, too, collateral arborizations are circumscribed and rather simple. An adjacent section processed for cytochrome oxidase failed to reveal whisker-related patterning $(A, B)$. Conventions are as in Figure 8. 


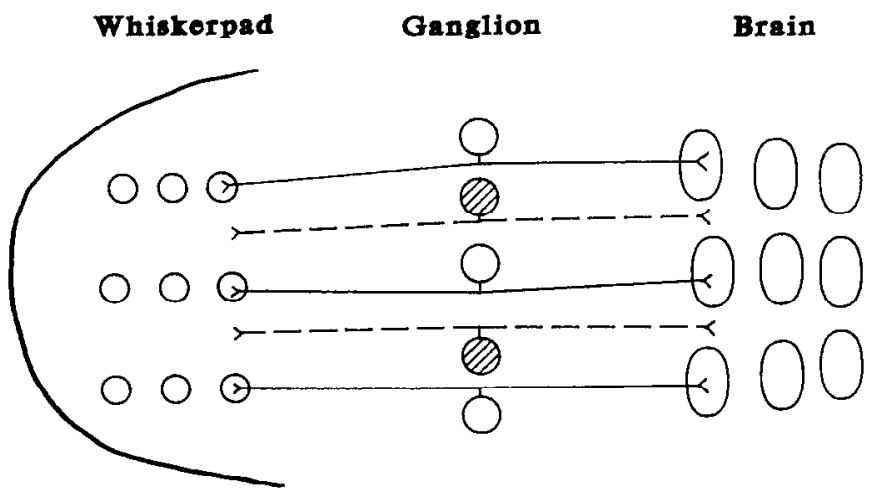

Figure 10. A hypothesis to account for whisker-related pattern formation in the $\mathrm{V}$ brainstem complex. The fetal $\mathrm{V}$ primary afferent pathway is schematized and includes the whisker follicles (circles) and intervening hairy skin, ganglion cells and their projections to nascent whisker-related patches (ellipses), and intervening "septa" in PrV. Insofar as naturally occurring ganglion cell death (hatched cell bodies) is extensive and regulated by a heterogeneous distribution of specific types and amounts of neurotrophic factors in the whisker pad, immature ganglion cells with axons projecting to peripheral receptor organs that lack sufficient trophic support, such as the hairy skin between whiskers, are largely eliminated during fetal life. If such cells project centrally to regions intervening between surviving and neighboring whisker projections, their death and central axon retraction would form "scpta" in brainstem regions between neighboring whisker projections.

peripheral branching patterns that compromise the "one whisker-one ganglion cell" substrate for central V pattern formation.

Second, aberrant peripheral axon collaterals, whether preserved or induced by the tropic actions of NGF (Gundersen and Barrett, 1979), might also result in one axon projecting to more than one type of peripheral receptor organ, such as a whisker follicle and adjacent hairy skin, something that is never seen normally (Jacquin et al., 1986; Rhoades et al., 1987). In a sense, such a scenario would lessen the disparity in the innervation densities of the whisker follicle and interwhisker surfaces, therein lessening the discontinuous ("digitized") character of the peripheral receptor sheet and its corresponding central representations.

Third, NGF augmentation also may preserve immature central primary afferent collaterals that would normally be eliminated or, alternatively, induce unusual collateral types by virtue of their enhanced trophic support. Our initial observations (presented here in Figs. 8, 9) of "simple" central arbors in NGFtreated animals are not consistent with either of these possibilities.

Fourth, increased levels of NGF might selectively influence the survival of a subpopulation of $\mathrm{V}$ ganglion cells, such as peptidergic neurons (Otten et al., 1980; Goedert et al., 1984; Yip et al., 1984), that do not normally project into regions with whisker-related patterns (Bennett-Clarke and Chiaia, 1992). Should peptidergic ganglion cells be disproportionately rescued by fetal NGF augmentation, their central projections might obscure an underlying pattern that is present in other cell types.

Fifth, it is possible that patterns do form after NGF augmentation, but only transiently as a result of the hyperinnervated $\mathrm{V}$ complex containing a disproportionate number of whisker-related axons whose arbors, by virtue of their enhanced trophic support, gain a competitive advantage for terminal space over other fiber systems that normally would come to occupy interpatch regions. Insights into the above listed possibilities could be gained by further anterograde tracing studies of the peripheral and central projections of specified subpopulations of $V$ ganglion cells at varying intervals after NGF augmentation.

A sixth possibility is that NGF may affect $V$ pattern formation by preserving or inducing projections to brainstem regions that normally come to lack such projections, such as the spaces normally demarcating neighboring whisker primary afferent projections. This possibility is discussed in detail below.

\section{Mechanisms underlying trigeminal pattern formation-a hypothesis}

During the normal development of somatotopic patterns, such as whisker-related patches in the $\mathrm{V}$ neuraxis, there appears to be a progressive sculpting of a single body representation. Whether in the axonal projections to the $\mathrm{V}$ brainstem complex, thalamus, or somatosensory cortex, a large single patch encompassing the entire territory devoted to the face is the first to appear (Jacquin and Rhoades, 1987; Schlaggar and O'Leary, $1991 \mathrm{~b}$; Senft and Woolsey, 1991). This single patch is then divided into five rows that correspond to the five rows of whiskers (Belford and Killackey, 1979a,b; Senft and Woolsey, 1991; Chiaia et al., 1992a). With time, these bands are further subdivided into individual patches, each corresponding to a single whisker.

Prior studies have shown that immature primary afferents exhibit remarkable precision in their projections to the whisker pad and the brainstem. Chiaia et al. (1993) have demonstrated single whisker receptive fields in E16 ganglion cells, suggesting adult-like projections to the whisker pad prior to the time of central pattern formation. Perhaps more telling, Erzurumlu and Jhaveri (1992) have shown that $1 \mathrm{~d}$ after $\mathrm{V}$ axons first enter the brainstem and long before patterns are evident, tracer deposits in the $A, C$, and $E$ row whisker follicles labeled alternating bands of fibers in the $\mathrm{V}$ spinal tract and $\mathrm{V}$ brainstem anlage in an adultlike fashion. Moreover, neither impulse blockade (Chiaia et al., 1992b; Henderson et al., 1992b) nor depletion of specific populations of $\mathrm{V}$ ganglion cells with antibodies to NGF (Sikich et al., 1986) or capsaicin (Nussbaumer and Wall, 1985) prevents the development of whisker-related patterns. Thus, short of axotomy, the afferent patterning mechanism is capable of withstanding considerable insult. What then is the patterning mechanism?

In conjunction with available data (reviewed above and in Henderson and Jacquin, in press), the presently described corrclations between NGF level, ganglion cell number, and pattern emergence in $\mathrm{V}$ primary afferent endings lead us to the following hypothesis to account for brainstem $\mathrm{V}$ pattern formation, as illustrated in Figure 10: Naturally occurring cell death in the $V$ ganglion is regulated by a heterogeneous distribution of specific types and amounts of neurotrophic factors in the periphery. Immature ganglion cells with axons projecting to peripheral receptor organs that lack sufficient trophic support, such as the skin and hairs between whiskers (Vos et al., 1991), are eliminated prenatally. Insofar as the relatively small number of such cells that survive to adulthood appear to preferentially project centrally to regions intervening between neighboring whisker projections (Jacquin et al., 1988b; P. J. Shortland and M. F. Jacquin, unpublished observation), their death and central axon retraction forms "septa" in brainstem regions intervening between those representing neighboring whiskers.

If this hypothesis survives experimental scrutiny, it would mean that septa formation, rather than patch formation, is the 
active developmental process that, in conjunction with orderly and somatotopic ingrowth of primary afferent collaterals, results in whisker-related pattern formation in the $\mathrm{V}$ brainstem complex. There is one result that, at first glance, would appear inconsistent with this hypothesis, that being the "blurring" of whisker-related patterns, with normal cell numbers, following one injection of NGF on E15. An alternative interpretation of these data is that the critical period(s) for pattern emergence can be delayed by a short-term application of NGF. A thorough analysis of the time course of naturally occurring cell death and pattern formation in this experimental group would shed light on this issue.

\section{References}

Armstrong-James M, Fox K (1987) Spatiotemporal convergence and divergence in the rat S1 "barrel" cortex. J Comp Neurol 263:265281.

Arvidsson J (1982) Somatotopic organization of vibrissae afferents in the trigeminal sensory nuclei of the rat studied by transganglionic transport of HRP. J Comp Neurol 211:84-92.

Barde Y-A, Edgar D, Thoenen H (1982) Purification of a new neurotrophic factor from mammalian brain. EMBO J 1:549-553.

Belford GR, Killackey HP (1979a) Vibrissae representation in subcortical trigeminal centers of the neonatal rat. J Comp Neurol 183: 305-322.

Belford GR, Killackey HP (1979b) The development of vibrissae representation in subcortical trigeminal centers of the neonatal rat. J Comp Neurol 188:63-74.

Bennett-Clarke CA, Chiaia NL (1992) Normal development and effects of neonatal infraorbital nerve damage upon the innervation of the trigeminal brainstem complex by primary afferent fibers containing calcitonin gene-related peptide. J Comp Neurol 324:282-294.

Bennett-Clarke CA, Chiaia NL, Jacquin MF, Rhoades RW (1992) Parvalbumin and calbindin immunocytochemistry reveal functionally distinct cell groups and vibrissa-related patterns in the trigeminal brainstem complex of the adult rat. J Comp Neurol 320:323-338.

Bocchini V, Angeletti PU (1969) The nerve growth factor: purification as a 30,000-molecular-weight protein. Proc Natl Acad Sci USA 64: 787-794.

Bothwell M (1991) Tissue localization of nerve growth factor and nerve growth factor receptors. Curr Top Microbiol Immunol 165:5570.

Carri NG, Soderstrom S, Ebendal T (1992) Neurotrophin receptor expression in the developing rat embryo. Soc Neurosci Abstr 18:1290.

Carroll SL, Silos-Santiago I, Frese SE, Ruit KG, Milbrandt J, Snider WD (1992) Dorsal root ganglion neurons expressing trk are selectively sensitive to NGF deprivation in utero. Neuron 9:779-788.

Catsicas S, Thanos S, Clarke PGH (1987) Major role for neuronal death during brain development: refinement of topographical connections. Proc Natl Acad Sci USA 84:8165-8168.

Chandler CE, Parsons LM, Hosang M, Shooter EM (1984) $\Lambda$ monoclonal antibody modulates the interaction of nerve growth factor with PC12 cells. J Biol Chem 259:6882-6889.

Chiaia NL, Bennett-Clarke CA, Rhoades RW (1991) Effects of cortical and thalamic lesions upon primary afferent terminations, distributions of projection neurons, and the cytochrome oxidase pattern in the trigeminal brainstem complex. J Comp Neurol 303:600-616.

Chiaia NL, Bennett-Clarke CA, Eck M, White FA, Crissman RS, Rhoades RW (1992a) Evidence for prenatal competition among the central arbors of trigeminal primary afferent neurons. J Neurosci 12:62-76.

Chiaia NL, Fish SE, Bauer WR, Bennett-Clarke CA, Rhoades RW (1992b) Postnatal blockade of cortical activity by tetrodotoxin does not disrupt the formation of vibrissa-related patterns in the rat's somatosensory cortex. Dev Brain Res 66:244-250.

Chiaia NL, Bauer WR, Rhoades RW (1993) Prenatal development of the receptive fields of individual trigeminal ganglion cells in the rat. J Neurophysiol 69:1171-1180.

Coggeshall RE (1992) A consideration of neural counting methods. Trends Neurosci 15:9-13.

Coggeshall RE, Chung K, Greenwood D, Hulsebosch CE (1984) An empirical method for converting nucleolar counts to neuronal counts. J Neurosci Methods 12:125-132.
Coggeshall RE, La Forte R, Klein CM (1990) Calibration of methods for determining numbers of dorsal root ganglion cells. J Neurosci Methods 35:187-194.

Cowan MW, Fawcett JW, O'Leary DDM, Stanfield BB (1984) Regressive events in neurogenesis. Science 225:1258-1265.

Davies AM, Lumsden AGS (1984) Relation of target encounter and neuronal death to nerve growth factor rcsponsivencss in the developing mouse trigeminal ganglion. J Comp Neurol 223:124-137.

Davies AM, Lumsden AGS, Slavkin HC, Burnstock G (1981) Influence of nerve growth factor on the embryonic mouse trigeminal ganglion in culture. Dev Neurosci 4:150-156.

Davies AM, Bandtlow C, Heumann R, Korsching S, Rohrer H, Thoenen $H$ (1987) Timing and site of nerve growth factor synthesis in developing skin in relation to innervation and expression of the receptor. Nature 326:353-358.

Dawson DR, Killackey HP (1985) Distinguishing topography and somatotopy in the thalamocortical projections of the developing rat. Dev Brain Res 17:309-313.

DiStefano PS, Johnson EM Jr (1988) Identification of a truncated form of the nerve growth factor receptor. Proc Natl Acad Sci USA 85:270-274.

Ernfors P, Merlio J-P, Persson H (1992) Cells expressing mRNA for neurotrophins and their receptors during embryonic rat development. Eur J Neurosci 4:1140-1158.

Erzurumlu RS, Jhaveri S (1990) Thalamic axons confer a blueprint of the sensory periphery onto the developing rat somatosensory cortex. Dev Brain Res 56:229-234.

Erzurumlu RS, Jhaveri S (1992) Trigeminal ganglion cell processes are spatially ordered prior to differentiation of the vibrissa pad. $\mathbf{J}$ Neurosci 12:3946-3955.

Erzurumlu RS, Bates CA, Killackey HP (1980) Differential organization of thalamic projection cells in the brainstem trigeminal complex of the rat. Brain Res 198:427-433.

Fenton EL (1970) Tissue culture assay of nerve growth factor and of the specific antiserum. Exp Cell Res 59:383-392.

Forbes DJ, Welt C (1981) Neurogenesis in the trigeminal ganglion of the albino rat: a quantitative autoradiographic study. J Comp Neurol 199:133-147.

Goedert M, Otten U, Hunt SP, Bond A, Chapin D, Schlumpf M, Lichtensteiger W (1984) Biochemical and anatomical effects of antibodies against nerve growth factor on developing rat sensory ganglia. Proc Natl Acad Sci USA 81:1580-1584.

Gorin PD, Johnson EM Jr (1979) Experimental autoimmune model of nerve growth factor deprivation: effects on developing peripheral sympathetic and sensory neurons. Proc Natl Acad Sci USA 76:53825386.

Greenough WT, Chang F-LF (1988) Dendritic pattern formation involves both oriented regression and oriented growth in the barrels of mouse somatosensory cortex. Dev Brain Res 43:148-152.

Gundersen HJG, Bagger P, Bendtsen TF (1988) The new stereological tools: dissector, fractionator, nucleator and point sampling intercepts and their use in pathological research and diagnosis. Acta Pathol Microbiol Immunol Scand 96:857-881.

Gundersen RW, Barrett JN (1979) Neuronal chemotaxis: chick dorsalroot axons turn toward high concentrations of nerve growth factor. Science 206:1079-1080.

Hallböök F, Ibánez CF, Persson H (1991) Evolutionary studies of the nerve growth factor family reveal a novel member abundantly expressed in Xenopus ovary. Neuron 6:845-858.

Hamburger V, Brunso-Bcchtold JK, Yip JW (1981) Neuronal death in the spinal ganglia of the chick embryo and its reduction by nerve growth factor. J Neurosci 1:60-71.

Hempstead BL, Martin-Zanca D, Kaplan DR, Parada LF, Chao MV (1991) High affinity NGF binding requires coexpression of the $t r k$ proto-oncogene and the low affinity NGF receptor. Nature 350:678683.

Henderson TA, Jacquin MF (in press) What makes subcortical barrels? Requisite trigeminal circuitry and developmental mechanisms. In: Barrel cortex, Vol 1 1, Cerebral cortex (Jones EG, Diamond I, eds), in press. New York: Raven.

Henderson TA, Osborne PA, Srisumrid R, Woolsey TA, Johnson EM, Jacquin MF (1991) Fetal injections of nerve growth factor interrupts whisker-related pattern formation in brainstem. Soc Neurosci Abstr 17:10.

Henderson TA, Osborne PA, Srisumrid R, Johnson EM, Woolsey TA, 
Jacquin MF (1992a) Why do whisker-related patterns fail to develop in the brainstem after fetal NGF injection? Soc Neurosci Abstr 18: 1098.

Henderson TA, Woolsey TA, Jacquin MF (1992b) Infraorbital nerve blockade from birth does not disrupt central trigeminal pattern formation in the rat. Dev Brain Res 66:146-152.

Heuer JG, Fatemie-Nainie S, Wheeler EF, Bothwell M (1990) Structure and developmental expression of the chicken NGF receptor. Dev Biol 137:287-304.

Hohn A, Leibrock J, Bailey K, Barde Y-A (1990) Identification and characterization of a novel member of the nerve growth factor/brainderived neurotrophic factor family. Nature 344:339-341.

Hosang M, Shooter EM (1985) Molecular characteristics of nerve growth factor receptors on PC12 cells. J Biol Chem 260:655-662.

Innocenti GM (1981) Growth and reshaping of axons in the establishment of visual callosal connections. Science 212:824-827.

Jacquin MF (1989) Structure-function relationships in rat brainstem subnucleus interpolaris. V. Functional consequences of neonatal infraorbital nerve section. J Comp Neurol 282:63-79.

Jacquin MF, Rhoades RW (1987) Development and plasticity in hamster trigeminal primary afferent projections. Dev Brain Res 31:161175.

Jacquin MF, Renehan WE, Klein BG, Mooney RD, Rhoades RW (1986) Functional consequences of neonatal infraorbital nerve section in rat trigeminal ganglion. J Neurosci 6:3706-3720.

Jacquin MF, Golden JP, Panneton WM (1988a) Structure and function of barrel "precursor" cells in trigeminal nucleus principalis. Dev Brain Res 43:309-314.

Jacquin MF, Stennett RA, Renehan WE, Rhoades RW (1988b) Structure-function relationships in rat brainstem subnucleus interpolaris II. Low and high threshold trigeminal primary afferents. J Comp

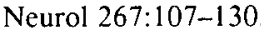

Jacquin MF, Hu JW, Sessle BJ, Renehan WE, Waite PME (1992) Intraaxonal Neurobiotin injection rapidly stains the long-range projections of identified trigeminal primary afferents in vivo: comparisons with HRP and PHA-L. J Neurosci Methods 45:7 1-86.

Jacquin MF, McCasland JS, Henderson TA, Rhoades RW, Woolsey TA (1993) 2-DG uptake patterns related to single vibrissae during exploratory behaviors in the hamster trigeminal system. J Comp Neurol 332:38-58.

Jacquin MF, Renehan WE, Rhoades RW, Panneton WM (in press) Morphology and topography of identified primary afferents in rat trigeminal subnuclei principalis and oralis. I Neurophysiol, in press.

Johnson EM Jr, Gorin PD, Brandeis LD, Pearson J (1980) Dorsal root ganglion neurons are destroyed by exposure in utero to maternal antibody to nerve growth factor. Science 210:916-918.

Johnson EM Jr, Osborne PA, Taniuchi M (1989) Destruction of sympathetic and sensory neurons in the developing rat by a monoclonal antibody against the nerve growth factor (NGF) receptor. Brain Res 478:166-170.

Killackey HP, Fleming K (1985) The role of the principal sensory nucleus in central trigeminal pattern formation. Dev Brain Res 22: 141-145.

Killackey HP, Jacquin MF, Rhoades RW (1990) Development of somatosensory system structures. In: Development of sensory systems in mammals (Coleman JR, ed), pp 403-429. New York: Wiley.

Klein R, Nanduri V, Jing SA, Lamballe F, Tapley P, Bryant S, CordonCardo C, Jones KR, Reichardt LF, Barbacid M (1991) The trkB tyrosine protein kinase is a receptor for brain-derived neurotrophic factor and neurotrophin-3. Cell 66:395-403.

Lamballe F, Klein R, Barbacid M (1991) trkC, a new member of the trk family of tyrosine protein kinases, is a receptor for neurotrophin3. Cell 66:967-979.

Levi-Montalcini R (1987) The nerve growth factor 35 years later. Science 237:1154-1162.

Ma PM, Woolsey TA (1984) Cytoarchitectonic correlates of the vibrissae in the medullary trigeminal complex of the mouse. Brain Res 306:374-379.

Maisonpierre PC, Belluscio L, Squinto S, Ip NY, Furth ME, Lindsay RM, Yancopoulos GD (1990) Neurotrophin-3: a neurotrophic factor related to NGF and BDNF. Science 247:1446-1451.

Martin-Zanca D, Barbacid M, Parada LF (1990) Expression of the $t r k$ proto-oncogene is restricted to the sensory cranial and spinal ganglia of neural crest origin in mouse development. Genes Dev 4:683-694. McLean IW, Nakane PK (1974) Periodate-lysine-paraformaldehyde fixative: a new fixative for immunoelectron microscopy. J Histochem Cytochem 22:1077-1083.

Nussbaumer JC, Wall PD (1985) Expansion of receptive fields in the mouse cortical barrelfield after administration of capsaicin to neonates or local application on the infraorbital nerve in adults. Brain Res 360:1-9.

O'Leary DDM, Fawcett JW, Cowan WM (1986) Topographic targeting errors in the retinocollicular projection and their elimination by selective ganglion cell death. J Neurosci 6:3692-3705.

Otten U, Goedert M, Mayer N, Lembeck F (1980) Requirement of nerve growth factor for development of substance $\mathrm{P}$-containing sensory neurones. Nature 287:158-159.

Reh TA, Constantine-Paton M (1985) Eye-specific segregation requires neural activity in three-eyed Rana pipiens. J Neurosci $5: 1132$ 1143.

Rhoades RW, Chiaia NL, Mooney RD, Klein BG, Renehan WE, Jacquin MF (1987) Reorganization of the peripheral projections of the trigeminal ganglion following neonatal transection of the infraorbital nerve. Somatosens Res 5:35-62.

Rhoades RW, Bennett-Clarke CA, Chiaia NL, White FA, Macdonald GJ, Haring JH, Jacquin MF (1990) Development and lesion induced reorganization of the cortical representation of the rat's body surface as revealed by immunocytochemistry for serotonin. J Comp Neurol 293:190-207.

Rhoades RW, Enfiejian HL, Chiaia NL, Macdonald GJ, Miller MW, McCann P, Goddard CM (1991) Birthdates of trigeminal ganglion cells contributing axons to the infraorbital nerve and specific vibrissal follicles in the rat. J Comp Neurol 307:163-175.

Rice FL, Van der Loos H (1977) Development of the barrels and barrel field in the somatosensory cortex of the mouse. J Comp Neurol 171:545-560.

Schecterson LC, Bothwell M (1992) Novel roles for neurotrophin are suggested by BDNF and NT-3 mRNA expression in developing neurons. Neuron 9:449-463.

Schlaggar BL, O'Leary DDM (1991a) Potential of visual cortex to develop an array of functional units unique to somatosensory cortex. Science 252:1556-1560.

Schlaggar BL, O'Leary DDM (1991b) A periphery-related pattern is evident in rat somatosensory cortex at birth. Soc Neurosci Abstr 17: 1126.

Senft SL, Woolsey TA (1991) Growth of thalamic afferents into mouse barrel cortex. Cereb Cortex 1:308-335.

Shatz CJ (1990) Impulse activity and the patterning of connections during CNS development. Neuron 5:745-756.

Sikich L, Woolsey TA, Johnson EM Jr (1986) Effect of a uniform partial denervation of the periphery on the peripheral and central vibrissal system in guinea pigs. J Neurosci 6:1227-1240.

Soppet D, Escandon E, Maragos J, Middlemas DS, Reid SW, Blair J, Burton LE, Stanton BR, Kaplan DR, Hunter T, Nikolics K, Parada LF (1991) The neurotrophic factors brain-derived neurotrophic factor and neurotrophin-3 are ligands for the $t r k \mathrm{~B}$ tyrosine kinase receptor. Cell 65:895-903.

Squinto SP, Stitt TN, Aldrich TH, Davis S, Bianco SM, Radziejewski C. Glass DJ, Masiakowski P, Furth ME, Valenzuela DM, DiStefano PS, Yancopoulos GD (1991) trkB encodes a functional receptor for brain-derived neurotrophic factor and neurotrophin-3, but not for nerve growth factor. Cell 65:885-893.

Taniuchi M, Johnson EM Jr (1985) Characterization of the binding properties and retrograde axonal transport of a monoclonal antibody directed against the rat nerve growth factor receptor. J Cell Biol 101: 1100-1106.

Van der Loos H (1976) Barreloids in mouse somatosensory thalamus. Neurosci Lett $2: 1-6$.

Van der Loos H, Woolsey TA (1973) Somatosensory cortex: structural alterations following early injury to sense organs. Science 179:395398.

Vongdokmai R (1980) Effect of protein malnutrition on development of mouse cortical barrels. J Comp Neurol 191:283-294.

Vos P, Stark F, Pittman RN (1991) Merkel cells in vitro: production of nerve growth factor and selective interactions with sensory neurons. Dev Biol 144:281-300.

Wong-Riley M (1979) Changes in the visual system of monocularly sutured or enucleated cats demonstrable with cytochrome oxidase histochemistry. Brain Res 171:11-28. 
Woolsey TA (1978) Some anatomical bases of cortical somatotopic organization. Brain Behav Evol 15:325-371.

Woolsey TA (1990) Peripheral alteration and somatosensory development. In: Development of sensory systems in mammals (Coleman JR, ed), pp 461-516. New York: Wiley.

Woolsey TA, Van der Loos H (1970) The structural organization of layer IV in the somatosensory region (SI) of the mouse cerebral cortex. Brain Res 17:205-242.

Yip HK, Johnson EM Jr (1984) Developing dorsal root ganglion neu- rons require trophic support from their central processes: evidence for a role of retrogradely transported nerve growth factor from the central nervous system to the periphery. Proc Natl Acad Sci USA 81: 6245-6249.

Yip HK, Rich KM, Lampe PA, Johnson EM Jr (1984) The effects of nerve growth factor and its antiserum on the postnatal development and survival after injury of sensory neurons in rat dorsal root ganglia. J Neurosci 4:2986-2992. 